\title{
PENENTUAN RUTE KENDARAAN MENGGUNAKAN METODE CLARK AND WRIGHT SAVING HEURISTIC (STUDI KASUS : PT. SINAR SOSRO)
}

\author{
Mariana Sianipar $^{1)}$, David Fu'ani ${ }^{2)}$, Wahyudi Sutopo ${ }^{3 *}$, dan Muhammad Hisjam ${ }^{4)}$ \\ ${ }^{1234)}$ Program Studi S1 Teknik Industri, Fakultas Teknik, Universitas Sebelas Maret, \\ Jl. Ir. Sutami No.36 Jebres, Surakarta, 57126, Indonesia \\ *) Coresponding Author: wahyudisutopo@staff.uns.ac.id
}

\begin{abstract}
Distribution and transportation are very vital for the company business beverages that must distribute its products to many areas of the consumer, for example is a bottled tea company. A good distribution plan and an optimum route would decrease cost and time for distributing the products. In a real case study for a bottled tea in Surakarta area, the fluctuating demand of consumers cannot be ensured and these mismatches by a salesman that should be based on the distribution plan and the realization of visit (RRK) resulted in the absence schedule. Therefore, it is required an optimum route to help the salesman in doing RRK or distribution without ignoring predetermined targets. There is a settlement solution will be more orderly preparation of these are using a Clark and Wright Saving Heuristic method. The method is able to assist the performance of salesmen and cost savings in the delivery of Surakarta area. In this paper, we have presented a real cases vehicle routing based on Clark-Wright algorithm to solve the open vehicle routing problem (OVRP) of bottled tea distribution in Surakarta District. We have modified the Clark Wright algorithm with three procedures composed of Clark and Wright formula. The methods of swap, 2 OPT and $3-$ OPT were used to improve our best solution in shortest route and the cheapest cost of distribution.
\end{abstract}

Keyword : 2-OPT, 3-OPT Method, Clark and Wright Saving Heuristic Method, Distribution Cost

\section{Pendahuluan}

Salah satu strategi yang bisa dilakukan untuk meningkatkan daya saing di dunia industri adalah dengan menerapkan Supply Chain Management. Supply Chain Management (Manajemen Rantai Pasok) adalah manajemen mengenai arus barang sejak dari sumber yang paling hulu sampai ke ujung hilir paling akhir yaitu konsumen. Manajemen arus barang ini lebih menekankan pada kelancaran pasokan barang, baik dari segi efisiensi maupun dari segi efektifitas (Indrajit dan Permono, 2005). Selain itu Supply Chain Management adalah koordinasi sistem strategis fungsi bisnis tradisional dan taktik seluruh fungsi-fungsi bisnis dalam suatu perusahaan tertentu dan di seluruh perusahaan dalam rantai pasokan, untuk tujuan meningkatkan kinerja jangka panjang perusahaan individu dan pasokan rantai secara keseluruhan (Mentzer dkk, 2001). Sedangkan menurut Pujawan I.N. (2005) Supply Chain Management merupakan koordinasi dari bahan, informasi dan arus keuangan antara perusahaan yang berpartisipasi dalam seluruh jenis kegiatan komoditas dasar hingga penjualan produk akhir ke konsumen. Penerapan Supply Chain Management diharapkan perusahaan mampu mengelola arus sumber daya yang ada secara lebih efisien dan efektif (Padmatyo \& Saputro, 2017). Salah satu kunci sukses dalam penerapan Supply Chain Management adalah dengan menerapkan strategi jaringan distribusi dan transportasi yang baik. Peran jaringan distribusi dan transportasi sangat vital bagi perusahaan. Kemampuan perusahaan untuk mengirimkan produk ke konsumen secara tepat waktu dan dan akurat menentukan kesuksesan sebuah produk di pasaran.

PT Sinar Sosro sebagai salah satu perusahaan nasional yang berfokus pada produksi minuman teh telah bertahan sekian lama dan tetap menjadi market leader untuk produk minuman teh terutama untuk segmen teh botol. Kesuksesesan Sosro dalam merebut hati konsumen sesungguhnya bisa dilihat dari aspek pemasaran dan distribusi yang cukup unik. Dalam pengembangan bisnisnya, PT. SINAR SOSRO telah mendistribusikan produknya ke seluruh penjuru Nusantara, melalui lebih dari 150 kantor cabang penjualan, serta beberapa Kantor Penjualan Wilayah (KPW). Untuk KPB SOSRO Ungaran memiliki kantor Pemasaran Wilayah Pusat yang berkedudukan di Semarang. Transportasi adalah perpindahan barang atau penumpang dari suatu tempat ketempat lain, dimana produk dipindahkan ke tempat tujuan dibutuhkan. Dan secara umum transportasi adalah suatu kegiatan memindahkan sesuatu (manusia dan/atau barang) dari suatu tempat ke tempat lain, baik dengan atau tanpa sarana (Bowersox, 1981). Manajemen Transportasi adalah kegiatan yang dilaksanakan oleh bagian transportasi atau unit dalam organisasi industri atau perdagangan dan jasa lain (manufacturing business and service) untuk memindahkan/mengangkut barang atau penumpang dari suatu lokasi ke lokasi lain secara efektif dan efisien (Nasution, M.N., 2004). 
Dalam menangani daerah pasaran yang cukup luas Kantor Pemasaran Wilayah dibagi lagi ke dalam Sub-sub Kantor Pemasaran Wilayah yang merupakan kepanjangan dari Kantor Pemasaran Wilayah. Untuk regional eks Karesidenan Surakarta dan sekitarnya dihandle oleh 2 buah Kantor Pemasaran Wilayah Sub yaitu Kantor Pemasaran Wilayah Sosro Sub Solo I yang berada di Solo Baru, Sukoharjo dan Kantor Pemasaran Wilayah Sosro Sub Solo II yang berada di Kartasura, Sukoharjo. Daerah cakupan pemasaran KPW Sosro Sub Solo I meliputi Solo Kota (Terbagi menjadi dua yaitu armada yang mensuplai produk ke target market umum/retailer/agen/toko dll, dan armada yang khusus mensuplai modern outlet dan lokasi makan), Sukoharjo, Wonogiri, Sragen, Sragen dan Karanganyar. Di Kantor Pemasaran Wilayah Sosro Sub Solo I dalam pendistribusian produknya menggunakan mobil cup tertutup (box) dan terbuka yang berjumlah 7 buah.

Dalam menjalankan aktifitas operasionalnya masalah penentuan rute dan penjadwalan merupakan masalah yang sering dihadapi oleh operasional transportasi perusahaan. Pihak manajemen pemasaran harus memutuskan konsumen mana yang harus dikunjungi oleh salesmennya, urutan kunjungannya, kendaraan mana yang dipakai ke konsumen mana serta rute mana yang harus dilalui setiap armadanya. Manajemen juga harus memastikan tidak ada armada yang kelebihan muatan dan pengiriman tidak melebihi batas waktu yang ditentukan. Selain itu juga terdapat masalah mengenai ketidaksesuaian rute oleh salesman terhadap Rencana dan Realisasi Kunjungan (RRK) yang telah ditentukan. Hal tersebut disebabkan oleh banyak faktor diantaranya salesmen lebih mendahulukan agen/distributor yang memiliki pesanan dengan jumlah yang lebih banyak, salesman kurang menyukai agen/distributor, hanya melakukan kegiatan penagihan ke agen/distributor dan lain sebagainya. Dalam kondisi riil terkadang ditemui kondisi dimana salesmen tidak mampu memenuhi target yang telah ditetapkan oleh RRK baik dalam hal penjualan maupun penagihan karena faktor rendahnya penjualan maupun macetnya dana dari agen/distributor padahal salesmen sudah mengeluarkan biaya dalam aktifitas transportasinya.

Dari kajian literatur, penentuan rute dan penjadwalan diklasifikasikan berdasarkan karakteristik sistem pengiriman, kapasitas kendaraan, tujuan penentuan rute dan penjadwalan (Haksever, 2000). Secara sederhana klasifikasi masalah penentuan rute dan penjadwalan sebagai berikut: Travelling Salesman Problem (TSP); Multiple Traveling Salesman problem (MTSP); Vehicle Routing Problem (VRP); dan Chinese Postman Problem (CPP). Untuk permasalahan pada artikel ini, maka model yang cocok digunakan adalah Vehicle Routing Problem, yaitu masalah penentuan rute dan penjadwalan dimana diadakan beberapa pembatasan misalnya kapasitas dari beberapa kendaraan atau waktu pengiriman serta ada kemungkinan permintaan atau situasi yang berubah-ubah. Permasalahan ini diklasifikasikan lagi menjadi beberapa jenis berdasarkan batasan yang ada (Kris Baekers dkk, 2016). VRP sendiri dapat berfungsi untuk menyelesaikan persoalan dimana keadaan pengiriman memiliki banyak titik dan dilakukan secara kontinyu pada suatu area. Sedangkan metode yang dipilih adalah metode Clark and Wreight Saving Heuristic. Clark and Wreight Saving Heuristic adalah satu metode heuristik yang digunakan untuk menyelesaikan permasalahan dalam transportasi untuk menentukan rute dan jadwal distribusi produk yang dikembangkan oleh Clarke dan Wright dengan tujuan untuk meminimalkan total jarak tempuh atau waktu atau biaya dengan mempertimbangkan armada yang digunakan (Anbuudayasanker, dkk. 2012; Surekha \& Sumathi, 2011; dan Sutopo, dkk 2007). Metode ini memiliki kelebihan diantaranya mudah diimplementasikan untuk menyelesaikan masalah yang kompleks.

Dari latar belakang diatas maka tujuan paper ini adalah untuk menentukan kombinasi rute yang tepat, sehingga dapat meminimasi biaya dengan mengurangi jarak yang ditempuh oleh armada dan lama waktu pengiriman setiap kendaraan serta mengurangi kesalahan pelayanan seperti pengiriman yang tertunda (Chopra, 2004).

\section{Metode Penelitian}

Penelitian ini menggunakan data primer dan data sekunder. Data primer didapat dari hasil observasi langsung dengan armada Kantor Pemasaran Wilayah Sosro Sub Solo I. Pengambilan data primer dilaksanakan pada bulan Juni 2016. Sedangkan data sekunder diperoleh dari hasil tinjauan pustaka. Langkah-langkah yang dilakukan dalam penelitian ini adalah: 


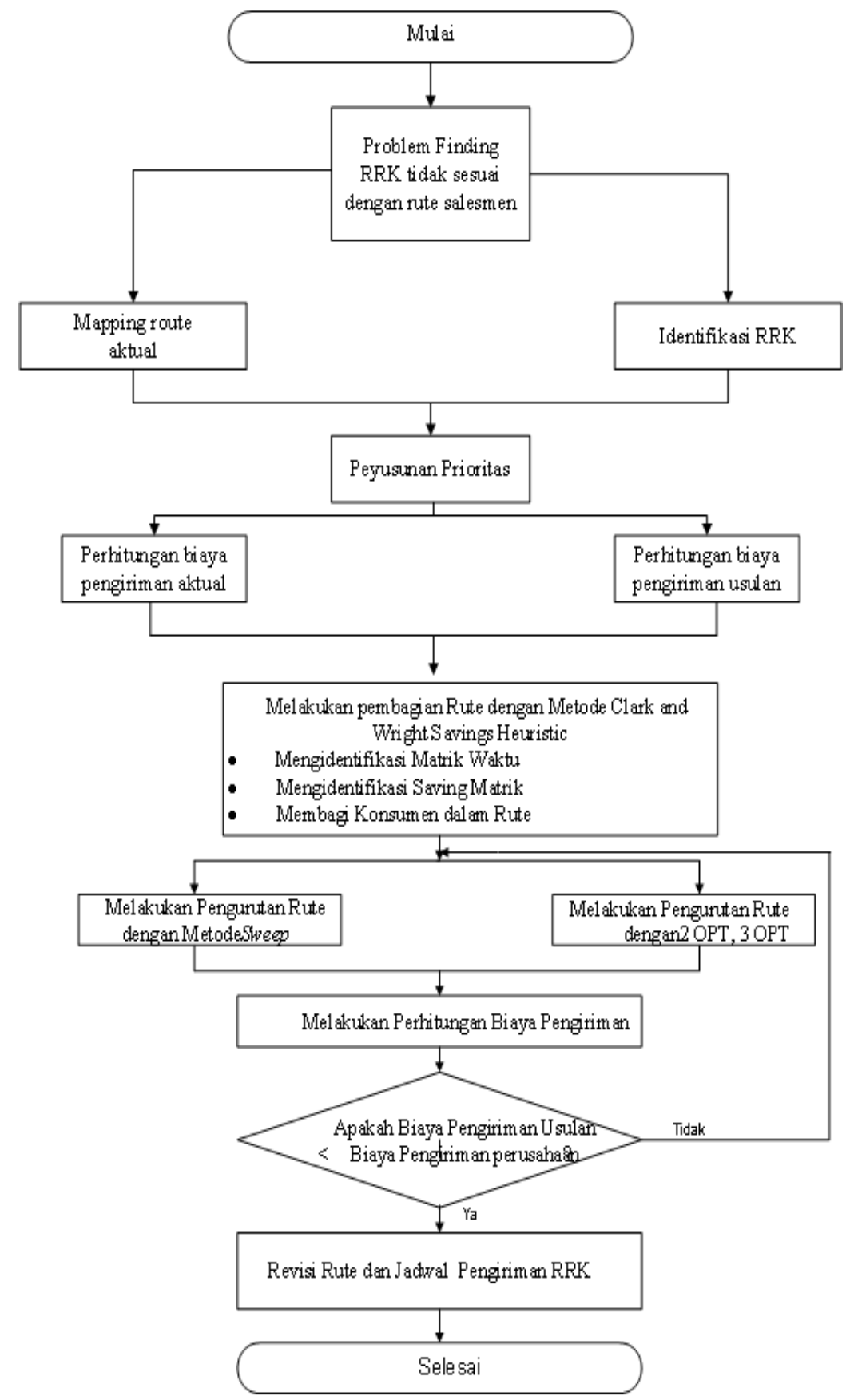

Tahap awal pada penelitian ini adalah penemuan masalah bahwa RKK tida sesuai dengan rute salesmen. Kemudian untuk menganalisis masalah ini dibagi menjadi dua tahapan yaitu mapping route aktual dan identifikasi Rkk. Setelah itu penyusunan prioritas. Tahap selanjutnya dibagi menjadi dua tahapan yaitu perhitungn biaya pengiriman aktual dan perhitungan biaya pengiriman usulan. Setelah itu melakukan pembagian rute dengan metode Clark and Wright Saving Heuristic. Tahap selanjutnya dibagi menjadi dua yaitu melakukan pengurutan rute dengan metode Sweep dan melakukan pengurutan rute dengan 2 OPT, 3 OPT. Tahap berikutnya melakukan perhitungan biaya pengiriman. Setelah itu menganalisis apakah biaya pengiriman usulan lebih kecil dari biaya pengiriman perusahaan. Jika hasil terbukti benar maka dapat dilakukan revisi rute dan jadwal pengiriman BKK.

\section{Hasil dan Pembahasan}

\subsection{Pengumpulan Data}

Data yang dikumpulkan merupakan data konsumen/outlet yang dilayani oleh kantor penjualan wilayah Solo dengan jumlah 80 konsumen yang tercatat. Kode konsumen dilambangkan dengan V (V1-V80), dimana V0 dilambangkan sebagai depot. Permintaan selama bulan Juni 2016 dapat dilihat secara terperinci pada tabel dibawah ini : 
Tabel 1. Daftar nama konsumen dan Rata-Rata Permintaan Konsumen per Kunjungan

\begin{tabular}{|c|c|c|c|c|c|c|c|c|c|}
\hline Kode & Konsumen & $\begin{array}{l}\text { Demand } \\
\text { (SKU) }\end{array}$ & \begin{tabular}{|c|} 
Frek \\
Kunjunga \\
$\mathrm{n}$
\end{tabular} & $\begin{array}{c}\text { Loading \& } \\
\text { Unloading } \\
\text { (Menit) }\end{array}$ & Kode & Konsumen & $\begin{array}{c}\text { Demand } \\
\text { (SKU) }\end{array}$ & \begin{tabular}{|c|} 
Frek \\
Kunjun \\
gan \\
\end{tabular} & $\begin{array}{c}\text { Loading \& } \\
\text { Unloading } \\
\text { (Menit) }\end{array}$ \\
\hline $\mathrm{V} 1$ & Toko Texas & 1 & 4 & 2 & V41 & Joko Nguw ek & 5 & 2 & 8 \\
\hline $\mathrm{V} 2$ & Toko Gede & 10 & 4 & 5 & $\mathrm{~V} 42$ & Toko Ria & 1 & 2 & 3 \\
\hline V3 & Toko Yulia & 1 & 2 & 2 & $\mathrm{~V} 43$ & Toko Joe Cell & 2 & 2 & 12 \\
\hline $\mathrm{V} 4$ & Toko Es Es & 5 & 4 & 5 & V44 & Bengkel Harsono & 1 & 2 & 5 \\
\hline V5 & Dee Salon SS & 5 & 2 & 5 & $\mathrm{~V} 45$ & Kantor Isuzu Astra International & 5 & 2 & 8 \\
\hline V6 & Bakso Mednas Sragen SS & 8 & 2 & 8 & V46 & Warung Agus & 10 & 3 & 10 \\
\hline $\mathrm{V} 7$ & Lilik TK & 6 & 3 & 6 & $\mathrm{~V} 47$ & Anda RM Masaran & 13 & 2 & 8 \\
\hline V8 & Mitra Sw alayan Sragen & 5 & 2 & 7 & $\mathrm{~V} 48$ & Juw ita Net & 9 & 2 & 7 \\
\hline V9 & Grosir Tri & 10 & 2 & 8 & V49 & Ayam Geprek & 10 & 3 & 7 \\
\hline $\mathrm{V} 10$ & U \& Me Salon & 1 & 2 & 1 & V50 & WR Dewi & 12 & 2 & 9 \\
\hline $\mathrm{V} 11$ & Creative Cell & 2 & 2 & 5 & V51 & Supermarket Toko Agung & 2 & 2 & 8 \\
\hline $\mathrm{V} 12$ & Toko Star & 0,3 & 2 & 5 & V52 & Mitra Cell & 4 & 2 & 4 \\
\hline $\mathrm{V} 13$ & Koperasi Giri Makmur & 4 & 2 & 4 & V53 & Turintia/SariWarna & 16 & 1 & 9 \\
\hline $\mathrm{V} 14$ & Toko Bu Isah & 4 & 2 & 4 & V54 & Pelanggan FUFN & 5 & 2 & 6 \\
\hline $\mathrm{V} 15$ & Dina Suroboyo Mojogendang & 5 & 2 & 6 & V55 & Hotel Pondok Indah & 120 & 4 & 30 \\
\hline $\mathrm{V} 16$ & SMA Mojogendang & 34 & 2 & 17 & V56 & Chuck Chiken & 23 & 2 & 10 \\
\hline $\mathrm{V} 17$ & Do Dugi RM & 18 & 2 & 12 & V57 & Suw ardi SS & 25 & 2 & 17 \\
\hline $\mathrm{V} 18$ & Raiman & 6 & 2 & 4 & V58 & Lapas Kop Sragen & 11 & 2 & 18 \\
\hline $\mathrm{V} 19$ & Plamboyan & 34 & 1 & 15 & V59 & RM Mutiara & 5 & 2 & 3 \\
\hline $\mathrm{V} 20$ & Sony Bakso & 9 & 2 & 7 & $\mathrm{~V} 60$ & Warung Makan Mentari Pagi & 5 & 2 & 5 \\
\hline $\mathrm{V} 21$ & Prima Motor & 1 & 2 & 7 & V61 & Ayam Goreng Bakar Cak Purbo & 11 & 2 & 13 \\
\hline $\mathrm{V} 22$ & Royal Steak & 20 & 2 & 19 & $\mathrm{~V} 62$ & Warung Nongkrong & 9 & 2 & 8 \\
\hline $\mathrm{V} 23$ & Pelanggan FUFN & 10 & 2 & 6 & $\mathrm{~V} 63$ & Kamdiyo & 17 & 1 & 16 \\
\hline $\mathrm{V} 24$ & Rumah Makan Embun Pagi & 10 & 2 & 11 & V64 & Kodim KOP Sragen & 15 & 2 & 10 \\
\hline $\mathrm{V} 25$ & Sony Bakso & 5 & 2 & 4 & $\mathrm{~V} 65$ & Kajen Mart & 130 & 2 & 35 \\
\hline $\mathrm{V} 26$ & Bengkel Mulya Jaya & 2 & 2 & 8 & $\mathrm{~V} 66$ & Amin Wartal Gaw an & 7 & 2 & 7 \\
\hline V27 & W.Makan Pringgodani & 2 & 2 & 10 & $\mathrm{~V} 67$ & Angkasa Net & 3 & 2 & 5 \\
\hline $\mathrm{V} 28$ & Toko Fauzan & 12 & 2 & 7 & $\mathrm{~V} 68$ & Toko Mulyani & 1 & 2 & 3 \\
\hline V29 & Toko Riska & 13 & 2 & 14 & V69 & SS SILAG & 54 & 1 & 18 \\
\hline $\mathrm{V} 30$ & Setya Jaya Motor & 16 & 2 & 13 & V70 & Sate Kambing Nadia & 5 & 2 & 5 \\
\hline V31 & Mbak Susi & 9 & 2 & 10 & V71 & Toko Koyu & 1 & 2 & 3 \\
\hline $\mathrm{V} 32$ & Dyt Gym & 9 & 2 & 12 & V72 & Do Dugi RM & 9 & 2 & 8 \\
\hline V33 & SLTPMunti & 5 & 3 & 10 & V73 & Toko Everty & 5 & 2 & 5 \\
\hline V34 & Endro Partatun & 27 & 1 & 15 & V74 & Kantor Isuzu Astra International & 4 & 2 & 10 \\
\hline V35 & Toko Sumber Jaya & 5 & 2 & 15 & V75 & Pojok TK & 3 & 2 & 5 \\
\hline $\mathrm{V} 36$ & Grosir Tri & 10 & 2 & 7 & V76 & Eka Kaliman & 10 & 2 & 9 \\
\hline V37 & W.Makan Pringgodani & 10 & 2 & 10 & V77 & Grosir Fadtullah & 420 & 1 & 72 \\
\hline V38 & Tri & 127 & 1 & 32 & $\mathrm{~V} 78$ & Rejeki Ngepos Tingkir & 14 & 2 & 13 \\
\hline V39 & Enak Bakso & 13 & 2 & 10 & V79 & Sumber Rejeki WR & 15 & 2 & 8 \\
\hline $\mathrm{V} 40$ & SMA 1 Sukadono & 5 & 2 & 10 & V80 & Timlo Masto & 3 & 2 & 7 \\
\hline
\end{tabular}

Tabel 2. Biaya Pengiriman

\begin{tabular}{|l|l|l|}
\hline No. & \multicolumn{1}{|c|}{ Biaya } & \multicolumn{1}{c|}{ Keterangan } \\
\hline 1 & Bahan Bakar Pickup & Rp.350.000 perminggu \\
\hline \multirow{3}{*}{2} & Gaji karyawan perbulan & \\
& - Gaji Salesman & Rp. 2.500 .000 perbulan \\
\hline 3 & - Gaji As. Salesman & Rp.2.100.000 perbulan \\
\hline 4 & Biaya perawatan perbulan & Rp.600.000 pertahun \\
\hline
\end{tabular}

\subsection{Pengolahan Data}

Terdapat beberapa tahap dalam pengolahan data yaitu dari penentuan outlet - outlet yang harus dilalui, kemudian menyusun rute usulan menggunakan metode Clark and Wright Saving Heuristic selanjutnya menentukan biaya pengiriman baik berdasarkan RRK, current condition Kantor Penjualan Wilayah Solo khususnya wilayah Sragen serta menentukan apakah rute usulan layak atau tidak berdasarkan biaya pengiriman yang diusulkan. Berikut tahapan pengolahan data yang digunakan :

\subsubsection{Penyusunan Rute Pengiriman dengan metode Clark and Wright Saving Heuristic Mengidentifikasi Matrik Jarak \& Waktu}


Tabel 3. Matrik jarak untuk V0-V5 (Km)

\begin{tabular}{|c|c|c|c|c|c|c|}
\hline $\begin{array}{c}\text { Ke / } \\
\text { Dari }\end{array}$ & 0 & V1 & V2 & V3 & V4 & V5 \\
\hline 0 & 0 & 34 & 32 & 50,3 & 42,8 & 47 \\
\hline V1 & 34 & 0 & 2 & 16,3 & 8,8 & 13 \\
\hline V2 & 32 & 2 & 0 & 18,3 & 10,8 & 15 \\
\hline V3 & 50,3 & 16,3 & 18,3 & 7,5 & 7,5 & 23,3 \\
\hline V4 & 42,8 & 8,8 & 10,8 & 79 & 0 & 14,2 \\
\hline V5 & 47 & 13 & 15 & 23,3 & 14,2 & 0 \\
\hline
\end{tabular}

Matrik jarak mendefinisikan jarak tempuh antar outlet dengan depot maupun jarak antar outlet. Jarak tempuh secara tidak langsung akan mempresesentasikan waktu tempuh kendaraan. Adapun kecepatan rata-rata kendaraan diasumsikan sebesar $50 \mathrm{Km} / \mathrm{Jam}$. Berikut merupakan konversi matrik jarak terhadap matrik waktu :

Tabel 4. Matrik Waktu untuk V0-V5 (Jam)

\begin{tabular}{|c|c|c|c|c|c|c|}
\hline $\begin{array}{c}\text { Ke / } \\
\text { Dari }\end{array}$ & 0 & V1 & V2 & V3 & V4 & V5 \\
\hline 0 & 0 & 0,68 & 0,64 & 1,006 & 0,856 & 0,94 \\
\hline V1 & 0,68 & 0 & 0,04 & 0,326 & 0,176 & 0,26 \\
\hline V2 & 0,64 & 0,04 & 0 & 0,366 & 0,216 & 0,3 \\
\hline V3 & 1,006 & 0,326 & 0,366 & 0,15 & 0,15 & 0,466 \\
\hline V4 & 0,856 & 0,176 & 0,216 & 1,58 & 0 & 0,284 \\
\hline V5 & 0,94 & 0,26 & 0,3 & 0,466 & 0,284 & 0 \\
\hline
\end{tabular}

\section{a. Perhitungan savings}

Langkah - langkah penghitungan saving sebagai berikut :

- Tentukan pasangan yang akan dihitung misal V1 dan V2

- Lakukan perhitungan dengan rumus

$$
\begin{aligned}
S(x, y)= & \text { waktu tempuh }(\text { Depot }, V 1)+\text { waktu tempuh }(\text { Depot }, V 2)- \\
& \text { waktu tempuh }(V 1, V 2) \\
= & 0,68+0,64-0,04 \\
= & 1,28 \mathrm{jam}
\end{aligned}
$$

Selanjutnya lakukan penghitungan lanjutan untuk keseluruhan pasangan, kemudian tentukan urutan nilai saving dari yang terbesar hingga terkecil. Kemudian buatlah list dari perhitungan savings sesuai dengan tahapan kedua pada algoritma Savings Heuristic.

\section{b. Membagi Outlet dalam Rute}

Langkah selanjutnya adalah pembagian konsumen dalam rute berdasarkan nilai saving yang

\begin{tabular}{|c|c|c|c|c|c|}
\hline & Kondifat (Vx, Vy) & Saving & & Koorulat (Vx, Vy) & Saving \\
\hline 1 & 15,18 & 2,724 & 11 & 16,6 & 2,204 \\
\hline 2 & 16,18 & 2,692 & 12 & 20,6 & 2,22 \\
\hline 9 & 20,18 & 2,68 & 19 & 6,2 & $2,2 x$ \\
\hline 4 & 15,16 & 2,68 & 14 & 19,3 & 2,112 \\
\hline 5 & 20,17 & 2,468 & 15 & 9,12 & 2,064 \\
\hline 6 & 16,17 & 2,468 & 16 & 10,12 & 2,04 \\
\hline 7 & 16,8 & 2,452 & 17 & 10,9 & 2,04 \\
\hline $\boldsymbol{s}$ & 8,15 & 2,44 & 18 & 12,3 & 2,012 \\
\hline 9 & 20,8 & 2,44 & 19 & 9,3 & 2,012 \\
\hline 10 & 15,9 & 2,386 & 20 & 10,14 & 1,912 \\
\hline
\end{tabular}
terbesar. Berikut merupakan 20 nilai saving terbesar terlihat pada tabel 6 yang akan digunakan sebagai acuan pembuatan rute.

Tabel 5. Daftar Ranking dari Saving

Berdasarkan urutan nilai saving, maka diperoleh pengelompokan untuk rute pertama armada truk yaitu V15, V18, V16, V20, V17, V8, V9, V6, V19, dan V12 dengan total pengiriman 88,3 SKU. Sedangkan untuk armada pickup yaitu V3, V10, V14, V1, V2, V4, V5, V7, V11, dan V13 dengan total pengiriman 56 . 


\subsubsection{Menentukan Urutan Kunjungan}

Adapun penentuan urutan kunjungan yaitu menggunakan metode Sweep dan 2-OPT, 3-OPT.

\section{a. Metode Sweep}

Langkah-langkah yang dilakukan dalam melakukan pengurutan kunjungan konsumen yaitu sebagai berikut:

i. Tetapkan depot $\left(\mathrm{V}_{0}\right)$ sebagai titik pusat perputaran pengurutan.

ii. Tetapkan armada truk dengan kapasitas 500 SKU sebagai armada pertama yang akan digunakan sebagai armada pengiriman produk ke konsumen.

iii. Lakukan sweeping dengan menarik garis berlawanan arah jarum jam dimulai dari titik pusat perputaran yaitu $\mathrm{V}_{0}$ berdasarkan hasil penentuan rute menggunakan urutan nilai saving matrik. Adapun Pengalokasian konsumen/ outlet disesuaikan dengan kapasitas dan jam kerja perusahaan. Saat telah melebihi kapasitas ataupun jam kerja maka akan dialokasikan ke armada berikutnya.

iv. Pengurutan konsumen/outlet dilakukan dengan menyesuaikan waktu total pengiriman dengan jam kerja perusahaan. Sebagai contoh untuk truk rute 1 diperoleh urutan V0 $\rightarrow \mathrm{V} 15 \rightarrow \mathrm{V} 18 \rightarrow \mathrm{V} 16 \rightarrow$ $\mathrm{V} 20 \rightarrow \mathrm{V} 17 \rightarrow \mathrm{V} 8 \rightarrow \mathrm{V} 9 \rightarrow \mathrm{V} 6 \rightarrow \mathrm{V} 19 \rightarrow \mathrm{V} 12 \rightarrow \mathrm{V} 0$ dengan total waktu tempuh rute sebesar 5,078 jam dan waktu loading 1,15 jam, sehingga total pengiriman produk sebanyak 88,3 SKU adalah 6,228 jam.

v. Hal yang sama dilakukan pada armada pick up. Sebagai contoh untuk armada pick up rute pertama diperoleh urutan perjalanan $\mathrm{V} 0 \rightarrow \mathrm{V} 3 \rightarrow \mathrm{V} 10 \rightarrow \mathrm{V} 14 \rightarrow \mathrm{V} 1 \rightarrow \mathrm{V} 2 \rightarrow \mathrm{V} 4 \rightarrow \mathrm{V} 5 \rightarrow \mathrm{V} 7 \rightarrow \mathrm{V} 11 \rightarrow \mathrm{V} 13 \rightarrow$ V0 dengan total waktu tempuh rute sebesar 3,058 jam dan waktu loading 0,98 jam, sehingga total pengiriman produk sebanyak $56 \mathrm{SKU}$ adalah 4,038 jam.

vi. Lakukan penghitungan hasil Sweeping untuk keseluruhan rute.

Tabel 6. Informasi Konsumen/Outlet dengan Waktu Tempuh Kendaraan, Waktu Loading \& Unloading, Waktu Pengiriman serta Jarak Pengiriman dalam Setiap Rute dengan Metode Sweep

\begin{tabular}{|c|c|c|c|c|c|c|c|}
\hline Finte & Anmen. & 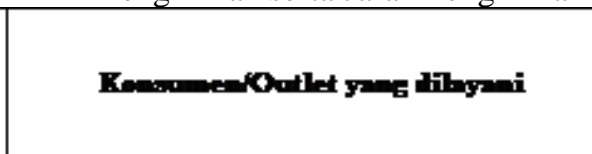 & $\mid \begin{array}{c}\text { Tetol } \\
\text { Pengi-i } \\
\text { (tiil) }\end{array}$ & 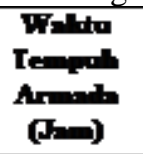 & 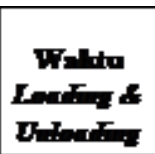 & 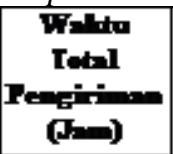 & 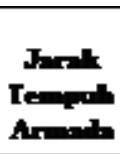 \\
\hline \multirow{2}{*}{1} & Tnit & 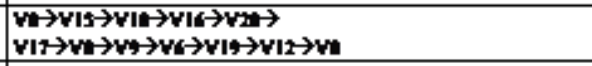 & 80,3 & 5,078 & 1.15 & 6,202 & 135 \\
\hline & $F=E$ U & 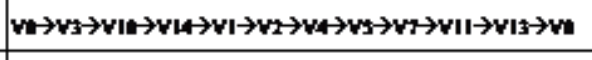 & 56 & 3,05 & 0,95 & 4,038 & $\mathbf{n}$ \\
\hline \multirow{2}{*}{2} & Tnt: & 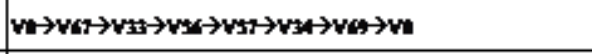 & 137 & 4,53 & 1,25 & 5,78 & 106 \\
\hline & $P=x U_{p}$ & 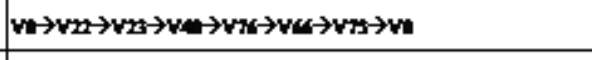 & 55 & 3,57 & 0,93 & 45 & 39 \\
\hline \multirow{2}{*}{3} & Tht & 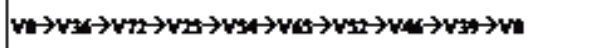 & 186 & 4,62 & 1,4 & 6,02 & 135 \\
\hline & $F=\ldots$ & 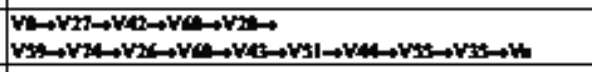 & 162 & 3,06 & 1,98 & 5,04 & 86 \\
\hline \multirow{2}{*}{4} & Tnt & 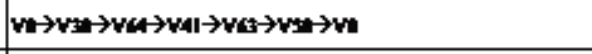 & 175 & 4,47 & 1,4 & 5,87 & 126 \\
\hline & $P=\ldots$ & 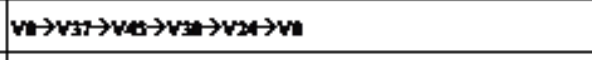 & 41 & 3,4 & 0,7 & 4,1 & 95 \\
\hline \multirow{2}{*}{5} & Tnt & 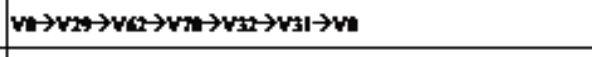 & 45 & 3,72 & 0,81 & 4,53 & 39 \\
\hline & $P=x U_{p}$ & 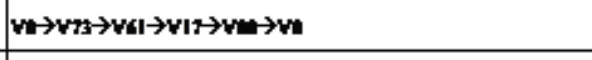 & 33 & 3,92 & 0,63 & 4,55 & 94 \\
\hline \multirow{2}{*}{6} & Tnt & 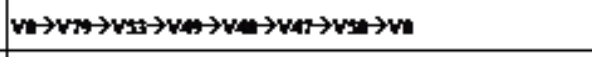 & 75 & 4,6 & 1,36 & 5,96 & 103 \\
\hline & $P=x U_{p}$ & 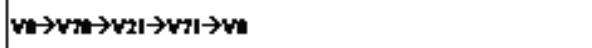 & 422 & 4,12 & 0,8 & 4,92 & 100,4 \\
\hline
\end{tabular}

b. Metode 2-OPT, 3-OPT

Langkah-langkah yang dilakukan dalam pengurutan kunjungan konsumen dengan menggunakan 2OPT, 3-OPT yaitu sebagai berikut:

i. Pengurutan kunjungan konsumen dimulai dari rute pertama untuk armada truk.

ii. Lakukan pemecahan perjalanan, dengan memecah perjalanan menjadi tiga titik untuk perjalanan dengan jumlah konsumen $\geq 6$ konsumen dan pecah perjalanan menjadi dua titik untuk perjalanan dengan jumlah konsumen $\leq 5$ konsumen.

iii. Hubungkan titik-titik perjalanan baru hasil pemecahan perjalanan tersebut yaitu tetap mempertimbangkan jam kerja kantor, kapasitas serta waktu pengiriman dengan syarat tidak melebihi batas yang telah ditentukan.

iv. Hitung kembali jarak yang ditimbulkan dari hasil penggabungan titik-titik perjalanan tersebut. Jarak terpendek yang dihasilkan dari penggabungan tersebut disimpan dan selanjutnya digunakan sebagai jarak tempuh rute hasil penggabungan tersebut.

v. Hasil pengurutan kunjungan konsumen/outlet dengan menggunakan metode 2-OPT, 3-OPT terdapat pada tabel 7 berikut ini : 
Tabel 7. Hasil Penyusunan Rute dengan Metode 2-OPT dan 3-OPT

\begin{tabular}{|c|c|c|c|c|c|c|c|}
\hline Tote & 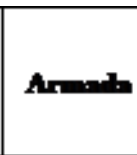 & 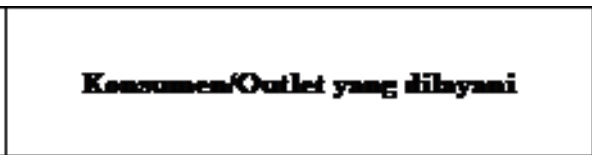 & 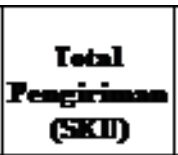 & 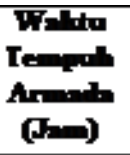 & 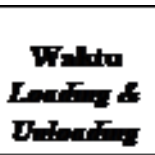 & 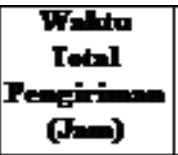 & 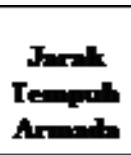 \\
\hline \multirow{2}{*}{1} & Tnit & 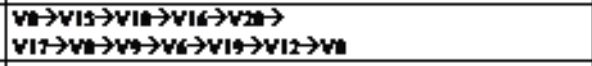 & $\mathbf{8 3} 3$ & 5,078 & 1.15 & 6,20 & 135 \\
\hline & $P=E U_{p}$ & 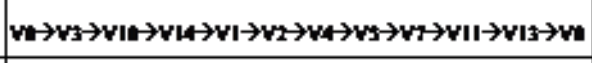 & 56 & 3,058 & 0,98 & 4,038 & $\pi$ \\
\hline \multirow{2}{*}{2} & Tnt & 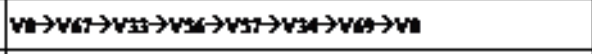 & 137 & 4,53 & 1,25 & 5,73 & 106 \\
\hline & Frex U & 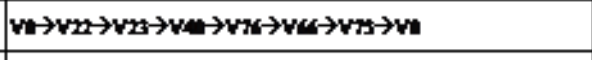 & 55 & 3,57 & 0,93 & 45 & 39 \\
\hline \multirow{2}{*}{3} & Tnt & 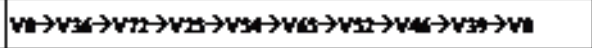 & 186 & 4,62 & 1,4 & 6,02 & 135 \\
\hline & $P=x U_{p}$ & 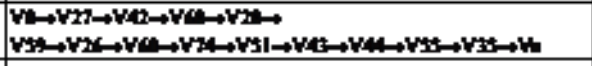 & 162 & 2,55 & 1,95 & 4,53 & 60 \\
\hline \multirow{2}{*}{4} & Tnil & 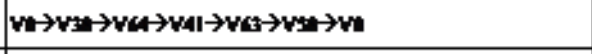 & 175 & 4,47 & 1,4 & 5,87 & 126 \\
\hline & $P=x$ & 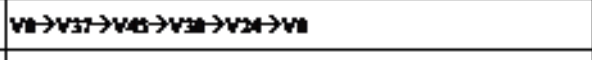 & 41 & 3,4 & 0,7 & 4,1 & 95 \\
\hline \multirow{2}{*}{5} & Tnt & 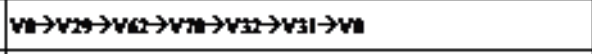 & 45 & $3, \pi 2$ & 0,81 & 4,53 & 89 \\
\hline & $P=E$ U & $\mathrm{v} \rightarrow \mathrm{wr} \rightarrow \mathrm{val} \rightarrow \mathrm{v}_{1} \rightarrow \mathrm{vm}_{\mathrm{m}} \rightarrow \mathrm{w}$ & 33 & 3,92 & 0,63 & 4,55 & 94 \\
\hline \multirow{2}{*}{6} & Tnt & 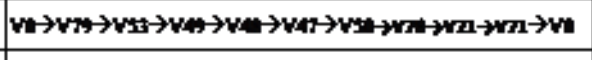 & 497 & 5,67 & 1,22 & 6,89 & 184,6 \\
\hline & $P=K U_{p}$ & - & & & & & \\
\hline
\end{tabular}

\subsubsection{Penentuan Biaya Pengiriman}

Biaya pengiriman merupakan biaya yang dikeluarkan oleh pihak kantor penjualan untuk kegiatan distribusi yang menggunakan alat angkut tertentu. Biaya transportasi terbagi menjadi dua yaitu fixed cost dan variable cost.

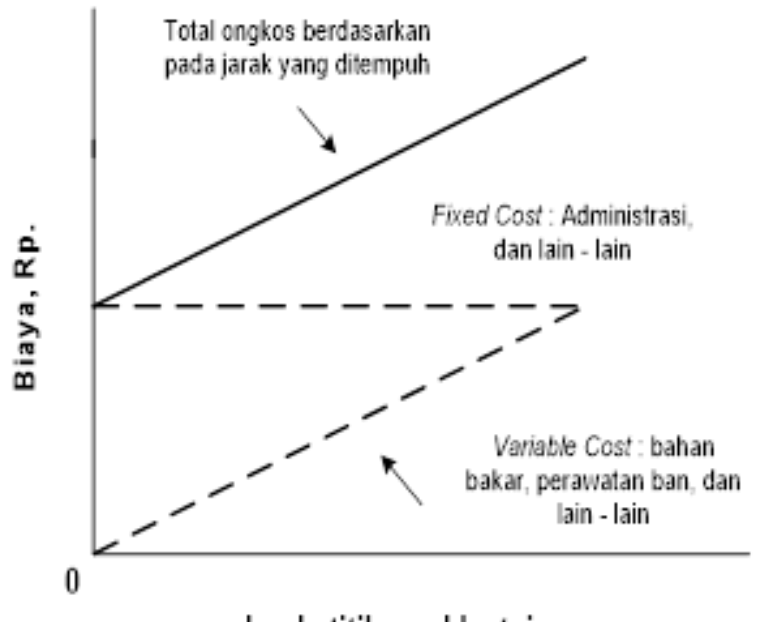

Jarak, titik awal ke tujuan

Gambar 2. Fungsi Biaya Angkut terhadap Jarak ( Sumber : Ballou, 1999 : 154 )

Rumus dalam penyelesaian biaya pengiriman adalah :

Transportation Cost $=$ Fixed Cost + Variable Cost

$$
=a+b \sum_{i=1}^{n} X_{i}
$$

Dimana : $a=$ fixed cost/bulan (Rp)

$b=$ variable cost $/ \mathrm{km}(R p)$

$x=$ jarak yang ditempuh $(\mathrm{km})$

Yang termasuk dalam fixed cost dalam penelitian ini adalah sebagai berikut :

1. Biaya tetap kendaraan ( penurunan nilai jual motor )

2. $\quad$ Biaya salesman asisten salesman ( Gaji)

Sedangkan yang termasuk dalam variable cost dalam penelitian ini adalah sebagai berikut :

1. Biaya bahan bakar

2. Biaya penggantian ban

3. Biaya penggantian minyak pelumas ( oli )

4. Biaya perawatan ( kampas rem, minyak rem, dan lain - lain ) 
Tabel 8. Perhitungan Biaya Pengiriman

\begin{tabular}{|c|l|r|r|}
\hline No. & \multicolumn{1}{|c|}{ Biaya } & $\begin{array}{c}\text { Metode } \text { Sweep } \\
\text { (per bulan) }\end{array}$ & $\begin{array}{r}\text { Metode 2- } \\
\text { OPT, 3-OPT }\end{array}$ \\
\hline 1 & Bahan Bakar Truk & $\mathrm{Rp} 1.400 .000$ & $\mathrm{Rp} 1.400 .000$ \\
\hline 2 & Bahan BakarPickup & $\mathrm{Rp} 910.000$ & $\mathrm{Rp} 910.000$ \\
\hline \multirow{2}{*}{3} & $\begin{array}{l}\text { Gaji karyawan perbulan } \\
\text { - Gaji Salesman }\end{array}$ & $\mathrm{Rp} .2 .500 .000$ & $\mathrm{Rp} .2 .500 .000$ \\
& - Gaji As. Salesman & $\mathrm{Rp} .1 .800 .000$ & $\mathrm{Rp} .1 .800 .000$ \\
\hline 3 & Pajak truk & $\mathrm{Rp} .60 .000$ & $\mathrm{Rp} .60 .000$ \\
\hline & Pajak pickup & $\mathrm{Rp} .50 .000$ & $\mathrm{Rp} .50 .000$ \\
\hline 4 & Biaya perawatan perbulan & $\mathrm{Rp} .350 .000$ & $\mathrm{Rp} .350 .000$ \\
\hline
\end{tabular}

\subsubsection{Menentukan Kelayakan Rute Usulan}

Penentuan kelayakan rute usulan diketahui dengan melakukan perbandingan biaya antara current condition maupun sesuai RRK (Rencana Realisasi Kunjungan). Apabila biaya pengiriman rute usulan lebih kecil dari biaya pengiriman sebelum adanya rute usulan, maka rute tersebut layak untuk diterapkan. Berikut perbandingan biaya pengiriman kantor penjualan dan rute usulan :

Tabel 9. Perbandingan Biaya Pengiriman

\begin{tabular}{|c|c|lc|}
\hline Keterangan & Jarak Tempuh $($ Km) & \multicolumn{2}{|c|}{ Biaya Pengiriman } \\
\hline Sesuai RRK & \pm 2600 & $\pm \mathrm{Rp}$ & 7.548 .180 \\
\hline Current Condition KP & Tidak diketahui dengan pasti & $\mathrm{Rp}$ & 7.548 .180 \\
\hline $\begin{array}{c}\text { Rute Usulan dengan metode } \\
\text { sweep }\end{array}$ & 2460,8 & $\mathrm{Rp}$ & 7.398 .906 \\
\hline $\begin{array}{c}\text { Rute Usulan dengan metode 2- } \\
\text { OPT \& 3OPT }\end{array}$ & 2411,2 & $\mathrm{Rp}$ & 7.345 .716 \\
\hline
\end{tabular}

Berdasarkan tabel 9 tersebut dapat disimpulkan bahwa penggunaan metode 2-OPT, 3-OPT menghasilkan biaya pengiriman yang lebih rencah dibandingkan biaya pengiriman rute usulan menggunakan metode sweep maupun yang diberlakukan oleh kantor penjualan tersebut. Penggunaan jadwal dan rute pengiriman dapat mengoptimalkan rute.

\section{Simpulan}

Penyusunan rute mengurangi biaya pengiriman sebesar Rp 149.274 untuk metode sweep dan penghematan biaya sebesar $\mathrm{Rp} 202.464$ metode 2-OPT,3-OPT. Rute usulan telah mampu mempertimbangkan jam kerja dan kapasitas armada. Rute usulan untuk metode 2-OPT, 3-OPT tetap 6 rute seperti metode sweep, perbedaannya adalah adanya pengubahan urutan dan penggabungan outlet. Salah satu contohnya yaitu pada rute 6 , muatan armada pickup dialihkan ke armada truk, sehingga armada pick up dapat digunakan untuk kunjungan bebas yang dapat menambah profit perusahaan. Sebaiknya Rencana Realisasi Kunjungan terus di update untuk membantu kinerja salesman. Sebaiknya rute dan jadwal perlu disusun ulang menggunakan metode Clark and Wright Saving Heuristic maupun metode 2-OPT,3-OPT sehingga pengiriman produk lebih teratur dengan biaya pengiriman yang leih rendah.

\section{Daftar Pustaka}

Anbuudayasankar, S.P, K. Ganesh, S.C. Lenny Koh, dan K Mohandas (2012). Modified Savings Heuristics And Genetic Algorithm For Bi-Objective Vehiclex Outing Problem With Forced Backhauls. Journal of Expert Systems with Applications, 39, 2296-2305.

Bowersox, D. J. (1981). Manajemen Logistik. Jakarta : Bumi Aksara.

Braekers, K., K. Ramaekers, I. V. Nieuwenhuyse. (2016). The Vehicle Routing Problem: State of the Art Classification and Review. Journal of Computers \& Industrial Engineering, 99, 300-313.

Chopra, S. \& Meindl, P. (2004). Supply Chain Management : Strategy, Planning, and Operation. New Jersey : Prentice Hall Inc.

Haksever C, B. Render, R. Russell, and R. Murdick. (2000). Service Management and Operations. Prentice Hall: Upper Saddle River, NJ.

Indrajit, E., dan Permono, A. (2005). Manajemen Manufaktur. Yogyakarta : Pustaka Fahima.

Mentzer, J. T., DeWitt, W., Keebler, J. S., Min, S., Nix, N. W., Smith, C. D., \& Zacharia, Z. G. (2001).

Defining Supply Chain Management. Journal of Business Logistics, 22, 1 - 25.

Nasution, M. N. (2004). Manajemen Transportasi. Jakarta : Ghalia Indonesia. 
Padmatyo, S \& Saputro, A. (2017). Peranan Manajemen Rantai Pasokan Terhadap Kualitas Produk Dan Efisiensi Distribusi, Proceedings Seminar Nasional dan The 4th Call for Syariah Paper, Surakarta, 22 Juli 2017, (ISSN:2460-0724), pp. 191-197.

Pujawan, I. N. (2005). Supply Chain Management. Surabaya : Gunawidya.

Surekha, P. and Sumathi, S. (2011). Solution To Multi-Depot Vehicle Routing Problem Using Genetic Algorithms. Journal of World Applied Programming, 1, 118-131.

Sutopo,W., Yuniaristanto, dan Widiyanti, B.R. (2007). Penyusunan Rute Pengiriman Es Balok Di PT. XYZ Menggunakan Metode Fisher And Jaikumar Algorithm. Jurnal Gema Teknik, 1, X.

Yuniarti, R. \& Astuti, M. (2013). Penerapan Metode Saving Matrix dalam Penjadwalan dan Penentuan Rute Distribusi Premium di SPBU Kota Malang. Jurnal Rekayasa Mesin, 4, 17-26. 